\title{
The knowledge commons
}

Reasserting the library as the heart of campus

$\mathbf{F}_{3}$ fteen years ago a colleague and I wrote a column for CERL News on the value of libraries as place. ${ }^{1}$ It was a point counterpoint piece in which I argued on the "place" side. My colleague, while not disputing this, argued that the library was more importantly transcending walls and physical space. It was a fun debate, but I was also a bit concerned about being perceived as the luddite, waxing nostalgic for the days of old. After all, in 1996 the digital era was dawning and we were caught up in millennium fever. The World Wide Web was revolutionizing everything. Who needed a physical library? Academic libraries would soon be housed in spaces the size of a thimble!

Well, here we are in 2011 and the world is indeed more technology-driven than in 1996. But a funny thing happened. I was right. Actually we were both right. "Library as Place" still very much exists, and technology has inarguably transformed libraries. What is surprising is that "Library as Place" may be more valid today than in 1996. How is this possible?

As a preface, the University of Central Florida (UCF) Libraries opened up its version of a knowledge commons. One can debate endlessly the definition of a knowledge commons and its derivative names. The UCF version is 22,000 square feet of wall-to-wall collaborative, technology equipped space featuring 190 desktop PCs, power outlets galore, comfortable seating, furnishings specifically designed for group collaboration, 32" wallmounted monitors in semi-enclosed study areas, and oversized workstations designed to accommodate multiple users. The environment features rolling white boards, flip up tablets, cup holders, electronic announcement boards, acoustical treatments, and visual and acoustical screening, all wrapped up in colors and fabrics to suit 21st-century tastes.

Students have taken to it by storm. On opening day, they poured into the space by the hundreds, creating an immediate energy and excitement not seen in the library in years. Building gate count is up 11 percent year-to-year. Reference questions are up a whopping 75 percent year-to-year, though this gain is due in part to double staffing after reopening. Student groups are working in clusters everywhere. They are using the white boards and oversize monitors, and enjoying the luxuriously large study and research carrels. Laptops and other portable devices are ubiquitous. Students are posting messages on Facebook and tweeting about the wonders of the commons. They are not just enjoying the renovated space, they are consuming it.

Of course none of this is new. Academic libraries have been repurposing space in this fashion for more than a decade. But to see the transformation with one's own eyes - the conversion of what was underused stack space, located in the most valuable area in the library, into a vibrant, collaborative, technology-driven student environment, delivers a strong message.

There are at least four reasons why the knowledge commons concept is so successful if done correctly, and why it is imperative to have such spaces.

Frank R. Allen is associate director for administrative services at University of Central Florida Libraries, e-mail: fallen@mail.ucf.edu

(c) 2011 Frank R. Allen 
Number 1: Online courses are curtailing face -to-face student interaction, yet human beings are inherently social creatures. Most of us live and thrive in communities. The decline of the traditional classroom is exacerbating students' interests in social learning spaces, whether students are consciously aware of it or not.

Number 2: Course work is increasingly team-based to reflect the desires of employers to hire graduates who can successful work together. Students will seek out spaces that facilitate group collaboration.

Number 3: 21st-century students demand and appreciate sound design and form. My freshman dormitory in 1976 (at a well regarded southern university) featured painted cinder block walls, cheap fixtures, VCT floors, and bed sets mounted on metal frames. The look was upscale penitentiary, and it was completely acceptable at the time. Those days are long gone. Today's students wish to operate in highly functional and attractive spaces.

Number 4: Knowledge commons type spaces make good business sense. Higher education has become ultra competitive. The elite universities and colleges are battling to get the cream of a slower growing number of high school graduates. ${ }^{2}$ The rest of the pack is also competing with each other, but additionally competing directly or indirectly with an explosion of online universities. One way traditional universities can maintain a competitive advantage is to not just offer online courses to meet those demands head on, but also capitalize on their superior physical environments. Knowledge commons spaces help reinforce the value of university campuses in their physical state, for which online universities have no answer.

Academic study/technology/learning spaces can occur virtually anywhere on campus, including hallways. ${ }^{3}$ This is good, and the more such spaces the better. Libraries offer compelling synergies however, that few other campus locations can match:

1. Professional assistance is only a few feet away. UCF Libraries relocated its reference and research desk to the center of the commons, both a symbolic and practical gesture. It is staffed by librarians who are trained to provide research and technology assistance. Other campus learning spaces often provide proctors or a modicum of assistance, but typically do not carry the service culture and expertise offered by the university library.

2. Students may derive utility in having a staffed service point nearby, even if they don't use it. Economists call this existence value. ${ }^{4}$ Existence value stems from the notion that simply knowing a resource exists can create a comfort level in the mind of a consumer, whether or not the resource is ever used.

3. Information resources and study materials are nearby. Not all materials are online . . yet. One of the most commons sights in the new UCF knowledge commons is of students huddled around a plastic model of a human skeleton, which is loaned in-house. Libraries are set up to handle this type of reserve lending.

4. For libraries fortunate to have an inhouse café, each is symbiotic with the other, providing added value to the time-constrained student.

5. There is an atmosphere of seriousness in a library that is unlike most other public spaces on campus. This stems from behavioral expectations, a staffed presence, and peer influence.

6. Many libraries are located conveniently near the center of campus. It is an easy rendezvous point for groups.

The online era is creating the need for equilibrium. For every minute students are online there is an equal and opposite reactional need for scholarly face-to-face time. This is why students are pouring into smartly designed collaborative/research spaces in libraries and other locations. What does the "Library of the Future" look like, and when is it coming? It has walls, is laden with technology, and it's already here.

\section{Notes}

1. Frank R. Allen and Sarah B. Watstein, "Point/Counterpoint: The Value of Place." CERL News 57, no. 6 (1996): 372-73.

(continues on page 492) 
In mid-April, Congress finally solidified the FY 2011 budget that will fund the government through September 30. Those who followed the Congressional soap opera know that this budget plan was the product of months of debate, which culminated in a budget that made $\$ 38.5$ billion in cuts compared to the FY 2010 levels, and included a 0.2 percent across-the-board cut for all nondefense discretionary spending.

Unfortunately, many programs of importance to libraries received funding cuts. However, one key program - the Census Bureau's Statistical Compendia Branch—survived the knife in 2011 but remains on the cutting board for 2012 .

The Statistical Compendia Branch compiles and releases reports such as the Statistical $A b$ stract and the County and City Data Book that includes important and usable data routinely accessed by the American public. Closing this branch would mean the end of these reports and easy access to this valuable data.

Providing usable, informative government information to the American public is required for a healthy democracy. Since 1878 , the U.S. Census has been compiling these data and making them available to the American people.

ALA has received numerous stories detailing how such reports as the Statistical Abstract have benefited the public and how deeply concerned they are at the potential loss of these resources. This information is used to teach college students about government information and statistics, help small businesses locate statistics about their county and environs, and provide university faculty with a go-to place for government data. Though some of this data is available in other locations, this compilation is created in such a way as to be usable to a wide variety of consumers.

It is also true that not all of the data included is published in other locations. If this avenue of openness is closed, the American

Jenni Terry is press officer at ALA's Washington Office, e-mail: jterry@alawash.org public will lose the ability to access this data in a usable format and in some cases, access would be denied completely.

ALA has long fought for effective public access to government information. The association believes that the loss of these important resources, in a time of striving for greater government transparency, is a step backward. It is a mistake to end usable access to this information without a plan in place to ensure that the public has another way to locate it.

Congress recently returned from the August recess and picked up the FY2012 budget process.

As ALA continues to lobby Congress to preserve funding for the Statistical Compendia Branch, members need to hear from residents in their states and districts who uses this tool.

We encourage all ACRL members to call their representatives offices. As always, you can connect with your representative through the ALA Legislative Action Center at capwiz. com/ala.

Those with questions about this issue can contact Jessica McGilvray, assistant director for the ALA Office of Government Relations in the ALA Washington Office, at (800) 941-8478. $\boldsymbol{n}$

("The knowledge commons," cont. from page 469)

2. National Center for Education Statistics predicts a decreased rate of growth in high school graduates in the second decade of the new millennium. nces.ed.gov/programs /projections/projections2018/sec3b.asp.

3. Larry MacPhee, "Learning Spaces: A Tutorial," EDUCAUSE Quarterly 32 (November 1, 2009), www.educause. e d u / E D U C A U S E + Q u a r t e r l y /EDUCAUSEQuarterlyMagazineVolum /LearningSpacesATutorial/163854

4. Existence value is most commonly used in environmental economics. An excellent treatment is www.eoearth.org/article/Total _economic_value. $\boldsymbol{n}$ 